\title{
Significance of Environmental Amenities in a Planned City: An Evidence from Chandigarh, India
}

\author{
Pradeep Chaudhry ${ }^{1}$, Mahendra Pal Sharma ${ }^{1}$ and G. Singh ${ }^{2}$ \\ ${ }^{I}$ Alternate Hydro Energy Centre, Indian Institute of Technology Roorkee, Roorkee-247667, India \\ ${ }^{2}$ Arid Forest Research Institute, Jodhpur-342005, India
}

\begin{abstract}
Good water quality urban lakes, wetlands and reasonably maintained green spaces have important amenity values that include provision of leisure and aesthetic enjoyment for the residents of the city. However, due to lack of proper quantification of the aesthetic and recreational benefits arising out of these assets, especially in developing countries, local municipalities fail to realize the real worth of such assets. The present study establishes a firm and positive link between market rates of residential plots on one hand and environmental attributes like good water quality lake proximity, green space proximity and better air quality on the other, in Chandigarh city of India. Results of the hedonic pricing models with linear and double log functional forms have been presented in the paper. Science based evidence has shown that people were willing to pay for environmental amenities through higher housing prices. The city administration has sufficient room to enhance current official collector rate of urban residential property up to $3000 \mathrm{~m}$ distance from the Sukhna lake, resulting in enhanced revenue generation. The results of the study can prove useful in urban land use planning, nature conservation and fixing property rates for the overall sustainable development of the cities in the developing countries like India.
\end{abstract}

Key words: Greenery, Hedonic pricing method, Residential property, Urban lake, Urban forestry

Submitted Date 22 June 2013

Accepted Date: 27 June 2013

\section{Introduction}

Urban sprawl consisting of concrete jungle and asphalt desert is increasing gradually in developing countries. Amidst tall buildings, fume-emitting automobiles, herd of fast moving working class people; the presence of open spaces in the form of urban lakes, wetlands, rivers and green spaces act as a balm to the cityworn soul. The quality and quantity of these resources act as obvious indicators of sustainable urban development. Sustainable management of such spots, which has the potential to mitigate the ill effects of urbanization, can make cities more attractive and comfortable to live in.

The quantum of ecosystem services generated by the lakes, wetlands and rivers at global level has been found much higher in comparison to other natural resources like forests though later occupy far more global area (4855 million ha) as compared to lakes, wetlands and wetlands (530 million ha). Total value of ecosystem services generated by lakes, wetlands and rivers at global level stands at U.S \$ 6.6 trillion/year in comparison to US \$ 4.7 trillion/year for the forests [1].

Quantification of intangible benefits like aesthetic and ecological in case of urban lakes, wetlands and green spaces in cities has not been getting due attention in developing countries, though of late, some studies have been undertaken in China during last one decade $[2,3,4,5,6,7,8]$. In India, no research study has been conducted till date quantifying effects of a good water quality urban water lake and green spaces on residential plots. However one study mentions about fetching Rs 558 and Rs 538 per square foot more value for the flats/apartments located near water bodies and green spaces respectively as compared to those away from these in Mumbai city [9]. Another study mentions about increase in property value near Bhoj wetlands in Bhopal city in comparison to those located away from it but affect of green spaces is not mentioned [10]. The present study was undertaken with the main objective to find effects of Sukhna lake and green space proximity in the form of parks and gardens, on the residential plots of the Chandigarh city. Flat or apartment culture is not much prevalent in the city, hence residential plots of different sizes were considered in the study. Other objective included verifying about the scope of revenue generation, if any, for the betterment of these two environmental resources of the city.

\section{Study Site}

Chandigarh, the common capital of the states of Punjab and Haryana, is different from other Indian cities in many ways: administered as a Union Territory by the Government of India, it is a city of seemingly vast spaces, completely planned with rectangular urban sectors, with basic amenities like water supply, drainage, 
sewerage made available to almost all the residents. The city was established after India's independence in 1947 , covering an area of $114 \mathrm{~km}^{2}$ at $30^{\circ} 44^{\prime} \mathrm{N}$ latitude, $76^{\circ} 53^{\prime} \mathrm{E}$ longitude and at an average altitude of $365 \mathrm{~m}$ above mean sea level. The city is bound on the northeast by the Shivalik range of Himalayas and Sukhna lake is located at the northeast corner of the city. Tree plantation and landscaping has been an integral part of the city's Master plan. The per capita green space availability in the city presently is around $55 \mathrm{sq} \mathrm{m}$ which is better than most of the European cities [11]. The most peculiar feature of the city's landscaping is the tree planting along roads, open spaces, green belts and around building complexes. Important parks and gardens of the city include Bougainvillea Garden, Zakir Rose Garden, Bamboo Valley, Hibiscus Garden, Garden of Fragrance, Topiary Park, Terraced Garden, Moonlit Park, Garden of Annuals, Cactus and Succulents Garden, Shivalik Garden, Dahlia Garden. Most of these parks/gardens form part of Leisure valley chain of parks/gardens which are located along a seasonal storm water drain running across the city (Figure 1).

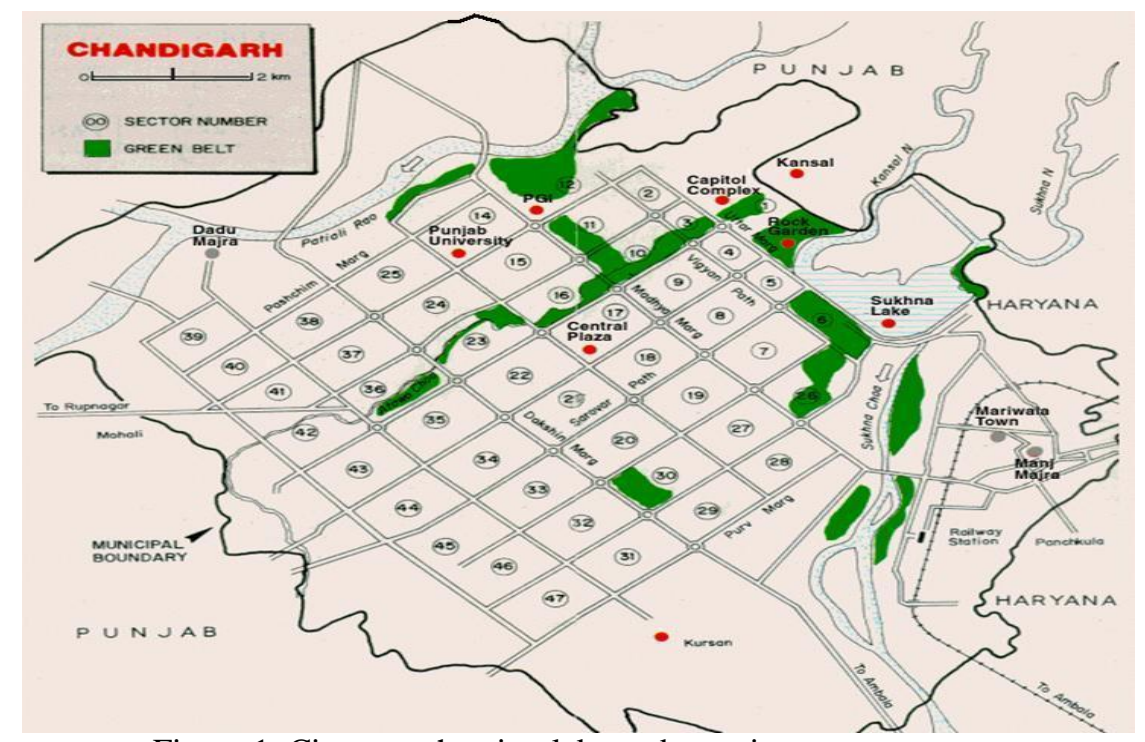

Figure 1: City map showing lake and prominent green spaces

The Sukhna Lake was formed in 1958 by constructing an earthen dam of about three kilometers in length and fourteen meters in height on Sukhna choe (a storm water drain). At present the lake is fed mainly by two hilly torrents, Kansal and Nepli choes. The total catchment area of the lake is 42 square kilometers, of which 33 square kilometers falls in the Shivalik hills and rest in few villages of Punjab state, Haryana state and Union Territory of Chandigarh city. Width of the top dam is $23 \mathrm{~m}$ and length of walk way is about 3 kilometers. The storage capacity, water spread area and average depth of the lake was $1074.4 \mathrm{ha} \mathrm{m}, 228.64$ ha and $5.5 \mathrm{~m}$ respectively during its formation in 1958, which are now reduced to 513.28 ha m, 148.28 ha and $1.1 \mathrm{~m}$ respectively in 2012 due to various reasons. The lake is mainly used as a tourist and recreation spot by the tourists and residents of the city with quality of water normally found 'good' except during rainy season when turbidity level goes high $[12,13]$.

\section{Materials And Methods}

Hedonic pricing method (HPM) was used for assessing the aesthetic benefit of Sukhna lake and green spaces. HPM estimates economic values for ecosystem services that directly affect the market prices of some other goods. In the present study, the 'ecosystem service' in question was aesthetic benefit of the lake \& parks/gardens and 'other goods' include residential plots in the residential sectors of Chandigarh. In practice, many attributes jointly contribute to the selling price of a house or a plot. Statistical techniques have been developed to separate parts of transaction prices due to each contributory attribute [3].

Primary data about prevailing market rates of residential plots in different sectors, where private residential plots are available, was collected during later part of the year 2012. Property dealers and residents of the city were contacted to get above details and data on air quality, drinking water quality and availability round the year, traffic noise, garbage removal from vicinity of their houses, quality of sector parks, distance of their houses from Sukhna lake and Leisure valley chain of parks and gardens was also collected from them.

Secondary data about air quality and noise pollution in residential areas of different sectors was collected from Chandigarh pollution control committee (CPCC), Department of Environment, Chandigarh administration. Deputy Commissioner, Chandigarh office was approached for finding out 'collector rate' applicable to sale and purchase of urban residential property in the city. 


\section{Results And Discussion}

Statistical package for social sciences (SPSS 16.0 for Windows) was used for multiple regression analysis. Market rate of residential plots (RATE) in Rs per sq yard was considered as dependent variable. The relationship between the dependent variable (RATE) and other independent variables can take several forms for regression analysis. Linear, semi $\log$ and double $\log$ specifications were considered for the present study. Results of linear and double log functional form are presented in the analysis as $\mathrm{R}^{2}$ and standard error estimate (SEE) values were found better in these cases than in the semi log form. The definitions of the dependent variable (RATE) and 8 explanatory variables included in this study are presented in Table 1. One variable i.e. size of residential plot (PLOTSIZE) is related to structural characteristics and rest are environmental variables. Last five variables are dichotomic in nature that takes value of 1 or 0 i.e. 1 for good air and water quality and 0 for bad quality. Similarly 1 is adopted for low traffic noise and 0 for higher noise disturbance. Variables other than PLOTSIZE can also be called hedonic variables as their inclusion in the price equation allows us assessing the influence of environmental attributes on housing market value.

Table 1. Definitions of variables related to plots and their environs

\begin{tabular}{|c|c|c|}
\hline Variable name & Definition & Unit \\
\hline RATE & $\begin{array}{l}\text { Market rate of residential plots in different } \\
\text { sectors }\end{array}$ & $\begin{array}{l}\text { Rs per sq } \\
\text { yard }\end{array}$ \\
\hline PLOTSIZE & Size of residential plots & Sq yard \\
\hline DISTLAKE & Distance of plot from Sukhna Lake & $\mathrm{m}$ \\
\hline DISTLVALLEY & $\begin{array}{l}\text { Distance of plot from Leisure valley chain } \\
\text { of parks/gardens }\end{array}$ & $\mathrm{m}$ \\
\hline AIRQUALITY & Quality of air in the vicinity of plot & 0,1 \\
\hline NOISE & Exposure to traffic noise & 0,1 \\
\hline GARBAGE & $\begin{array}{l}\text { Garbage removal facility from house \& in } \\
\text { the vicinity of plot }\end{array}$ & 0,1 \\
\hline WATERQUALITY & $\begin{array}{l}\text { Quality and availability of drinking water } \\
\text { during the year }\end{array}$ & 0,1 \\
\hline QUALITYSECPARKS & $\begin{array}{l}\text { Quality of sector parks in comparison to } \\
\text { Leisure valley }\end{array}$ & 0,1 \\
\hline
\end{tabular}

Table 2 presents a summary of descriptive statistics for the data used, including sample means, maxima, minima, and standard deviations. The sample includes 176 residential plots (of different sizes) which were available for sale and number of residents in these sectors who opined about the environmental variables mentioned in Table 3. The average rate of residential plot was ₹ 1,42,000/- per sq yard with a range between $₹ 2,20,000 /$ - and ₹ $90,000 /$ - per sq yard; average plot size was 628 sq yard, distance to lake averaged $3720 \mathrm{~m}$ and distance to Leisure valley chain of parks and gardens averaged $1600 \mathrm{~m}$.

Table 2: Statistical summary of the data

\begin{tabular}{|l|l|l|l|l|}
\hline Variable & Mean & Maximum & Minimum & Std. Dev. \\
\hline RATE (Rs/sq yard) & $1,42,000$ & $2,20,000$ & 90,000 & 26477.40 \\
\hline PLOTSIZE (sq yard) & 628 & 4000 & 100 & 792.44 \\
\hline DISTLAKE (m) & 3720 & 6971 & 286 & 1867.10 \\
\hline DISTLVALLEY (m) & 1600 & 3800 & 50 & 989.32 \\
\hline
\end{tabular}

The results of the hedonic price linear model are presented in Table 3 . The set of explanatory variables accounts for about $69 \%$ of the plot rate variance $\left(\operatorname{Adj} \mathrm{R}^{2}=0.693\right)$ and the $\mathrm{F}$ ratio test indicates that the model fits properly.

Table 3: Residential plot rate determinants (Linear specification)

\begin{tabular}{|llll|}
\hline Independent variable & Coefficient & t-ratio & p-value \\
\hline PLOTSIZE & -6.70 & -3.63 & 0.00 \\
DISTLAKE & -9.20 & -10.77 & 0.00 \\
DISTLVALLEY & -5.60 & -4.15 & 0.00 \\
AIRQUALITY & 5258.22 & 1.932 & 0.05 \\
NOISE & 255.65 & 0.168 & 0.946 \\
GARBAGE & -3135.06 & -0.836 & 0.404 \\
WATERQUALITY & 7006.97 & 2.523 & 0.01 \\
QUALITYSECPARKS & 10009.58 & 3.744 & 0.00 \\
CONSTANT & 198511.85 & 24.09 & 0.00 \\
\hline
\end{tabular}

Adj $R^{2}=0.693, \quad F=47.12(p<0.00)$, Dep. variable = RATE, $n=176$ 
A close look at t-ratio or students' t-statistics in above table indicates that distance from the lake $(\mathrm{t}=10.77)$, distance from Leisure valley $(\mathrm{t}=4.15)$ and quality of sector parks $(\mathrm{t}=3.744)$ are the top three independent variables affecting plot rates. The rates of residential plots decrease @ Rs 9.20 per sq yard as the distance from the lake increases. This is also reflected in Figure 2. Similarly rates of plots decrease @ Rs 5.60 per sq yard as the distance from Leisure valley chain of parks/gardens increases.

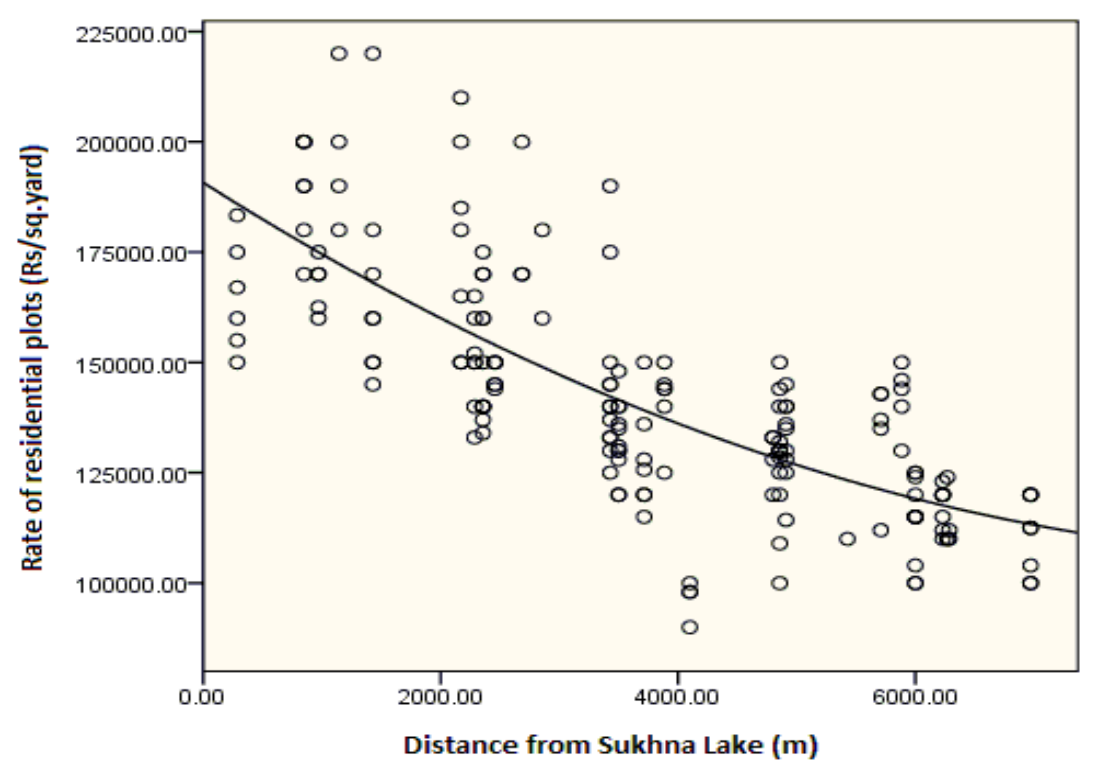

Figure 2: Variation of plot rates with distance from the lake

Table 4 gives the estimation of double log model using weighted least square (WLS) method. Variable 'zone' was used as the source variable for the weight in above software. In double log form, natural log is applied on both sides of the equation (except on dichotomic variables) describing relationship between price or rate of housing to various variables. The set of explanatory variables was found to account for more than two third of the rate variance $\left(\operatorname{Adj} \mathrm{R}^{2}=0.678\right.$ ) and the $\mathrm{F}$ ratio test indicated that model fits properly. The results indicate that all independent variables are significant except exposure to traffic noise and garbage removal variables. A close look at the Student's t-statistics reveals that distance from the lake was most significant variable affecting the rates of residential plots. Rates of plots decrease @ $10.5 \%$ per zone as the distance from lake increases.

Table 4: Multiple regression analysis results using WLS method (double log form)

\begin{tabular}{|llll|}
\hline Independent variable & Coefficient & t-ratio & p-value \\
\hline In PLOTSIZE & -0.024 & -1.90 & 0.05 \\
In DISTLAKE & -0.105 & -5.54 & 0.00 \\
In DISTLVALLEY & -0.019 & -2.36 & 0.01 \\
AIRQUALITY & 0.031 & 3.72 & 0.00 \\
NOISE & 0.00 & 0.00 & 0.99 \\
GARBAGE & 0.00 & -0.05 & 0.95 \\
WATERQUALITY & 0.048 & 5.10 & 0.00 \\
QUALITYSECPARKS & 0.068 & 4.05 & 0.00 \\
CONSTANT & 12.64 & 51.92 & 0.00 \\
\hline Adj R ${ }^{2}=0.678, \mathrm{~F}=46.98$ (p<0.00), Log-likelihood function value $=160.982, \mathrm{n}=176$ \\
\multicolumn{2}{|c|}{ Source variable for weighting=Zone, Dependent variable=In RATE }
\end{tabular}

However, the rates of plots decrease at lesser rate of $1.9 \%$ per zone as distance from Leisure valley chain of parks/gardens increases. This means that the effect of lake proximity is more influential on property prices than the green belt. Similarly, the rates of plots decrease @ $2.4 \%$ as plot size increases (Table 4). This is a general feature in Indian property market in majority of cities where smaller size residential plots fetch higher selling rate. Among other environmental variables, drinking water quality, its availability round the year and air quality are affecting the rates of property as the zones nearer to lake have the advantages of having better quality of air and drinking water availability. Quality of sector parks was also as an important variable (tstatistics=4.05), indicating comparatively better quality of sector parks in areas near to the lake and poorer quality in southern sectors of the city which are away from the lake. 
The traffic noise was not found to influence the rates of plots. This finding is similar to the finding in Chinese city of Guangzhou [2,3] but opposite to European countries [14]. People of the city found traffic noise present in almost all the areas, except few pockets near Zone 1 and 2. Secondary data from CPCC of Chandigarh administration also points out towards the same fact [15].

Hedonic pricing studies involving influence of environmental amenities with water bodies and green spaces as main ingredient on housing prices in developed and developing countries have been conducted with 'price' or 'rate' of residential flats as dependent variable[14,3,8,4]. Present study is the first of its kind where 'rate' of 'residential plots' has been taken as dependent variable because of the reason mentioned elsewhere in the article.

Ambient air quality of Chandigarh city is under pressure since last three decades due to increase in vehicle population. Chandigarh pollution control committee (CPCC) has established permanent air pollution monitoring stations at Punjab Engineering College (PEC) University of Technology at sector 12, Main market of sector 17 and at Institute of Microbial Technology (IMTECH), sector 39. Respirable Suspended Particulate Matter (RSPM) in the city is crossing its permissible limits of 60 micro grams per $\mathrm{m}^{3}$ in all the residential areas where monitoring is done by CPCC (Figure 3 and 4). But sectors far away from Sukhna lake (Figure 4) have been found with more concentration of RSPM than sectors near to lake (Figure 3).

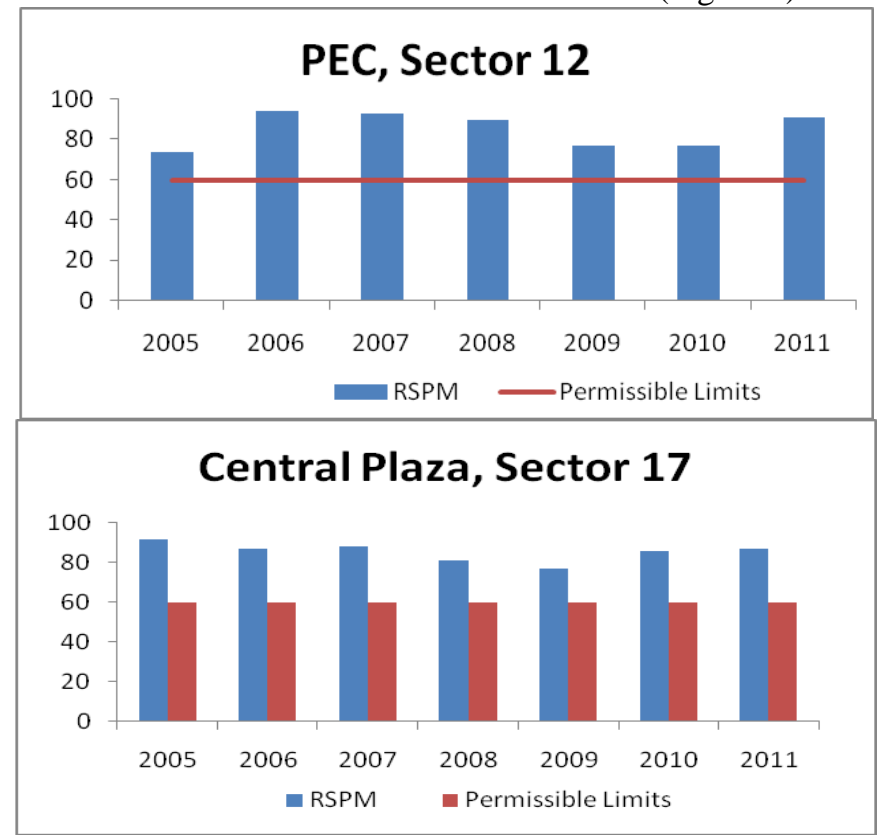

Figure 3: RSPM levels near Sukhna lake sectors (within aerial distance of $3.0 \mathrm{~km}$ )

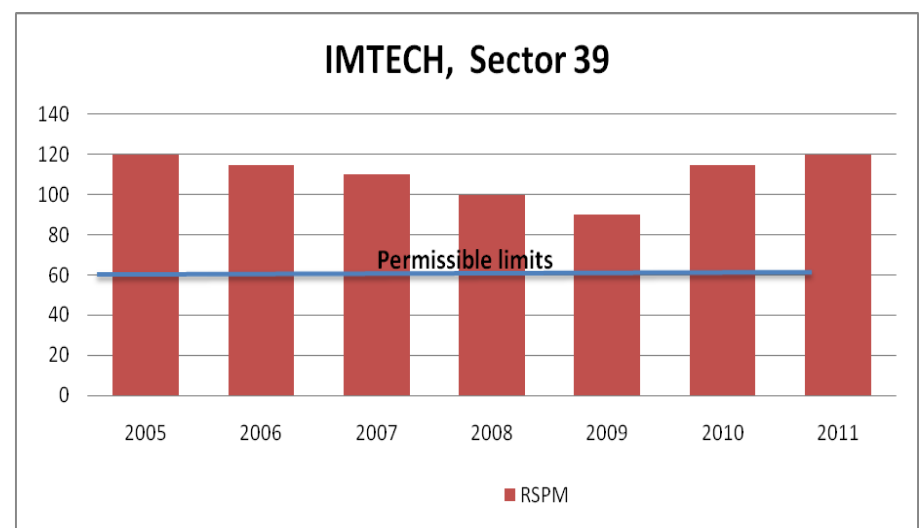

Figure 4: RSPM levels in far away sectors from the lake

One of the main reasons for better air quality in areas nearer to Sukhna lake (Figure 3) seems to be better urban greenery (Figure 1) and quality of sector parks in comparison to areas away from the lake (Table 3 and 4). In fact, research in thickly populated developing countries like China proved that urban vegetation removed considerable RSPM from the atmosphere in the cities. For example, urban forests of Guangzhou city of

China, covering an area of 7360 ha, removed 312 metric tons of atmospheric pollution annually, out of which $\mathrm{PM}_{10}$ accounted for 234 metric tons [5]. Similarly, urban greenery of Beijing, China with 4.5 million 
human population, was responsible for removal of 1261 metric tons of environmental pollution every year, out of which 776 metric tons were particulate matter [16].

Duncan multiple range test (DMRT), a kind of two way ANOVA, indicated that $>73 \%$ of residents were satisfied with air quality up to an aerial distance of $3000 \mathrm{~m}$ from the lake whereas less than $54 \%$ were satisfied as distance from lake increased more than $3000 \mathrm{~m}$. When 'quality of sector parks' was selected as dependent variable, it was noticed that nearly cent percent residents are satisfied with quality of sector parks up to $1500 \mathrm{~m}$ from the lake and about two thirds were satisfied up to $3000 \mathrm{~m}$ from the lake. Less than one third of residents were satisfied with quality of sector parks after $3000 \mathrm{~m}$ distance from the lake. The steeper slope of curve in Figure 2 (rate of plots vs distance from lake) up to $3000 \mathrm{~m}$ also indicates that areas nearer to the Sukhna lake enjoy maximum aesthetic benefit due to lake proximity.

Research in both developed and developing countries has also shown that better quality of urban vegetation in vicinity was responsible for enhanced property prices [17, 18, 14, 4, 8]. Better urban greenery in the form of sector parks and other gardens in the region nearer to Sukhna lake seems to enhance rates of residential property in Chandigarh city. In fact, Chandigarh city is among top India's cities having forest and tree cover of more than $35 \%$ of its area and per capita green space availability around $55 \mathrm{~m}^{2}[11,19]$. Maximum of this forest and tree cover is concentrated near the Sukhna lake (Figure 1).

Properly planned, developed and maintained urban lakes/wetlands and green spaces in the cities has the potential to guide urban development by providing a framework for economic growth and nature conservation [20]. These assets have the capacity to provide numerous ecosystem services like purification of air and water, mitigation of floods and droughts, local climate amelioration, carbon sequestration and enhancing landscape quality. Hence new cities, particularly in developing world, must contain these elements in the master plan of the individual cities to achieve ecological, economic and social sustainability.

Presently, the government approved collector rate for all the urban residential areas in the Chandigarh is uniform @ Rs 54,912/- per sq yard [21]. This rate is very less in comparison to prevailing residential property market rates in region nearer to the lake (Figure 1). Ideally, the collector rate should be very near to prevailing market rate of the property. The huge gap not only leads to the loss of government revenue in the form of stamp duty and registration charges applicable for selling/purchase of such property, it also encourages circulation of black money in the economy as investment in real estate is one of the most favorable options for the persons/firms having black money. Use of unaccounted money in property market in India has become a major problem $[22,23,24]$. Hence, there is an immediate need to enhance the present collector rate for urban residential property in the city from Rs 54, 912/- per sq yard to at least Rs 1,50,000/- per sq yard for the sectors falling in an aerial distance of $3000 \mathrm{~m}$ from the lake, this means sectors 2 to 19 and sectors 26, 27 and 28. Extra revenue generated, thereby, can be utilized for creating better parks/gardens in sectors devoid of greenery, maintaining the existing parks/gardens and the lake. In order to ensure sustainability of urban ecosystems, especially in near future when urban populations are bound to increase in India and other developing countries, such kinds of revenue generation mechanisms need to be explored [20]. This will also help in curbing increased air and noise pollution, as it has been proved not only in developed countries but also in a densely populated city of Dhaka, Bangladesh, a developing country where the research concluded that urban vegetation was very effective in controlling air and noise pollution [25]. This will result in mitigating ill effects of climate change and making the city environmentally sustainable in the long run.

\section{Conclusion}

People are generally aware of market or tangible benefits of lakes, rivers and forests e.g. water used for irrigation, drinking or boating purposes, fish production, timber and fuel wood derived from forests but very few of them know about non market or intangible benefits of these assets like water flow regulation, climate amelioration, carbon sequestration, recreational, educational and aesthetic benefits. There exists a general lack of understanding about the multiple benefits associated with these ecosystems due to the complexity and invisibility of spatial relationships among various constituents like ground water, surface water, water bodies' flora and fauna [26]. Present study is a small step in this direction and provides significant information about people's attitude and behavior towards such amenities in a developing country like India. More and more such studies should be conducted in different cities of the country, wherever possible, to provide scientific justification and platform for generating revenues for creating and maintaining the urban nature components like lakes, wetlands, parks and gardens. Municipalities in developing countries always struggle in financing urban nature conservation projects. We have tried to establish through this study that the local municipalities can generate sufficient revenue to further consolidate urban nature elements and provide better quality of urban life and recreational /leisure opportunities to the citizens. This study can also serve as a model for future city planning in the country as the city planners, architects and policy makers can consider the information about the utility of water bodies and urban green spaces in urban land use planning. 


\section{Acknowledgement}

One of the authors (PC) would like to express gratitude to National River Conservation Directorate (NRCD), Ministry of Environment and Forests, Government of India, New Delhi for sponsoring him to pursue two years M. Tech. programme (2011-13) in 'Environmental Management of Rivers and Lakes' being offered by Alternate Hydro Energy Centre, Indian Institute of Technology, Roorkee, India. The authors also express sincere thanks to the officials of different departments of Chandigarh administration and people of the city for providing facts, figures and various valuable data about the environmental attributes for this study.

\section{References}

[1] R. Costanza, d'Arge.R, de Groot, R., S. Farbe, M Grasso, K. Limburg, B. Hannon, S Naeem, R.V. O’Neill, R.G. Raskin, P. Sutton and M. Vanden Belt, The value of the world's ecosystem services and natural capital, Nature, 387, 1997, $253-260$.

[2] C.Y Jim and W.Y. Chen, Perception and attitude of residents towards urban green spaces in Guangzhou (China), Environmental Management, 38, 2006a, 338-349.

[3] C.Y Jim and W.Y. Chen, Impacts of urban environmental elements on residential housing prices in Guangzhou (China), Landscape and Urban Planning, 78, 2006b, 422-434.

[4] C.Y. Jim and W.Y. Chen, Consumption preferences and environmental externalities: A hedonic analysis of the housing market in Guangzhou, Geoforum, 38, 2007, 414-431.

[5] C.Y. Jim and W.Y. Chen, Assessing the ecosystem service of air pollutant removal by urban trees in Guangzhou, Journal of Environmental Management, 88, 2008, 665-676.

[6] C.Y Jim and W.Y. Chen, Value of scenic views: Hedonic assessment of private housing in Hong Kong, Landscape and Urban Planning, 91, 2009, 226-234.

[7] C.Y Jim and W.Y. Chen, External effects of neighborhood parks and landscape elements on high-rise residential value, Land Use Policy, 27, 2010, 662-670.

[8] F. Kong, H. Yin and N. Nakagoshi, Using GIS and landscape metrics in the hedonic price modeling of the amenity value of urban green space: A case study in Jinan city, China, Landscape and Urban Planning, 79, 2007, 240-252.

[9] V. Gupta and G. Mythili, Valuation of urban environmental amenities: A case study, International journal of Ecological Economics and Statistics, 19, 2010, 20-32.

[10] M Verma and D Negandhi, Valuing ecosystem services of wetlands-a tool for effective policy formulation and poverty alleviation, Hydrological Sciences Journal, 56(8), 2011, 1622-1639.

[11] P. Chaudhry, and V.P. Tewari, Urban forestry in India: Development and research scenario, Interdisciplinary Environmental Review, 12(1), 2011, 80-93.

[12] P. Chaudhry, M.P. Sharma, R. Bhargava, S. Kumar and P.J.S. Dadhwal, Water quality assessment of Sukhna Lake of Chandigarh city of India, Hydro Nepal: Journal of Water, Energy and Environment,12, January, 2013a, 26-31.

[13] P. Chaudhry, R. Bhargava, M.P Sharma and V.P. Tewari, Conserving urban lakes for tourism and recreation in developing countries: A case from Chandigarh, India, International Journal of Leisure and Tourism Marketing ,3(3), $2013 \mathrm{~b}, 267-281$.

[14] J. Luttik, The value of trees, water and open space as reflected by house prices in Netherlands, Landscape and Urban Planning, 48, 2000, 161-167.

[15] Department of Environment, State of Environment, Chandigarh-2008. A publication by ENVIS Centre in collaboration with Department of Environment, 2008, Chandigarh administration

[16] J. Yang, J. McBride, J. Zhou and Z. Sun, The urban forest in Beijing and its role in air pollution reduction, Urban Forestry \& Urban Greening, 4, 2005, 115-123.

[17] E.G. McPherson, J.R. Simpson, P.J Peper and Q Xiao, Bebefit-cost analysis of Modesto's municipal urban forest, Journal of Arboriculture, 25, 1999, 235-248.

[18] L.Tyrvainen and A Miettinen, Property prices and urban forest amenities, Journal of Environmental Economics and Management, $39,2000,205-223$.

[19] P.Chaudhry, K.Bagra and B.Singh, Urban greenery status of some Indian cities: A short communication, International Journal of Environmental Science and Development, 2(2), 2011,98-101.

[20] V.S Singh and D.N Pandey, Balancing environment with urban growth in India. RSPCB occasional paper no 6/2012. Accessed at www.rpcb.nic.in on June 30, 2013.

[21] Chandigarh administration, C.A, Information provided under Right to Information to the leading author by Deputy Commissioner, Chandigarh office vide no DC/DRA/2012/551 dated 05/11/2012.

[22] S. Nayar, The Indian Real Estate Market: A comprehensive analysis for the foreign investors. M .Arch dissertation submitted to Massachusetts Institute of Technology, USA, 1996.

[23] A. Kumar, The black economy in India, Penguin Books India Pvt Ltd, New Delhi, India, 2002.

[24] R.K.M. Bhigania, Black money and its implication, Indian Streams Research Journal, 2(4), 2012, 1-4.

[25] M.N. Islam, K.S. Rahman, M.M. Bahar, M.A. Haba, K. Ando and N. Hatturi, Pollution attenuation by roadside greenbelts in and around urban areas, Urban Forestry \& Urban Greening, 11, 2012, 460-464.

[26] R.K. Turner, J.C.J.M. Bergh, T. Soderqvist, A. Barendregt, J. Straaten, E. Maltby and E.C Ierland, The value of wetlands: Landscape and institutional perspectives, Ecological Economics, 35, 2000, 7-23. 